\title{
An Activity using a Personal Blog as Reflective Learning among University Students in Academic Writing Course
}

\author{
Khotimah Mahmudah ${ }^{1}$,Nur Arifah Drajati ${ }^{1}$ \\ ${ }^{1}$ Universitas Sebelas Maret, Ir. Sutami Street 36A Kentingan Surakarta, 57126, Indonesia. \\ Coresponding Author: khotimah.mahmudah@yahoo.com
}

\begin{abstract}
A blog has long been used in the field of education in which it is still a blog designed for certain groups and purposes. However, the use of students' personal blog is still rarely used. In responding to the case, a teacher has several creative ways to deliver academic writing materials to the students. One of those ways utilizes a task which uses a personal blog as a platform in the process of learning. This paper reports on a case study, which involves 30 freshmen of postgraduate students. The objectives were to create an opportunity for students to express personal opinions about certain topics and interests in writing blog entries, and to investigate the perspectives of an activity using a blog as reflective learning among university students. The researcher collected the data from observing blog pages, and doing document analysis. Because this research was seen from the perspectives, it needed an in-depth interview. The finding reveals that creating blog entries have a positive impact on students' writing skill, and encourage students' motivation to produce an academic writing in the context of English for Foreign language. The implication is that blogging activity has several benefits to students for enhancing deep critical thinking.
\end{abstract}

Keywords: Academic Writing; Blogging; Case Study; Reflective Learning; Writing in EFL.

\section{INTRODUCTION}

Recent research has shown that an effectiveness of using the academic blog as reflective learning is to enhance the motivation of students, and to enrich social interaction in an advanced language course [1]. The other research has presented that an activity which posts a writing on blog encourages students to be more concerned with correctness in conveying their ideas, and they reflect the opinions of themselves [2]. The researcher also utilized an idea from previous study about an action in doing peer review on blogging pages; most students as the participants had confessed that there was no problem with the reviewing process [3]. However, a classroom blog had been used to investigate the impact of a blog itself in any fields of science, and most of researches used a classroom blog which was designed by a teacher [4]. This paper used a personal blog designed by students in the context of academic writing.

The history of the blog itself is necessary to gauge information why a blog became famous recently. The use of a blog was started at the beginning of the World Wide Web for a forum of discussion related to current news in a computer system in the 1980s. It continued until in the 1990s that a post in blog became a diary or personal journal, but allowed people to give feedbacks and exchange experience [5]. Nowadays, a blog has become a unique tool for digital literacy. The widely used 
varieties of blog give contributions in the institutional research and in the field of higher education, such as a means to deliver, to collaborate, and to develop knowledge management [6]. In fact, from previous observation, most students read blog entries, but only a few students write in a blog log. Although they have easy access to use blog application. With this opportunity, one of the tasks in Academic Writing Course is that the students need to practice their writing skill in EFL toward a personal blog. The other reason is that the scheduled course is not sufficient to fulfill all targets in a semester. It means that a lecturer needs another way to accomplish all the objectives. A blog is a platform used in this research which is aimed to help students more experienced in writing EFL outside of teaching class.

For this paper, the researcher used an approach established for a way to run this research in the field. It referred to blended learning approach. The use of BL approach is supported by this reference: New systematic studies of various institutional methods and experiences will enrich and advance a community engagement through a more blended view of teaching, research, and service [7]. The agenda focused on the local and global issue of blended learning in which a blogging activity is a platform for a reflective learning outside of class. Following those references, a particular instruction related to a blog task is designed in BL approach. A blog job takes $20 \%$ proportions of the whole meetings. It used a personal blog to support students to enhance writing skill; such as creating own book summary and doing peer review.

In the other hand, the recommendations of reflective learning are essential as a foundation to build this research why a blog is a platform for reflective learning. Dewey, J. in Farrell [8] stated that a reflection is an act of deliberate and intentional way encouraging people to move with purposes and plans for future. For example source, there is a successful research about reflective thinking toward tagging support in team blogs in which the study explains how students manipulate the ideas in purposeful and conscious attitude toward meaning learning [9]. For this case, the researcher followed those ideas to examine the impact of a personal blog through students such as writing summaries and doing peer review in a personal blog.

\section{The Roles of Reflective Learning in Academic Writing}

The use of reflection in academic writing was found in Zhang [6]: The reflection: (1) creates enlightening way on the style and capacity of students' writing, (2) makes students be aware to determine preferred approaches to produce a writing product, and create students' bravery to attempt new things and more challenging strategies on an individual task, (3) creates an opportunity to examine own reflections in writing when doing activity such as peer review, and search other ways or approaches to learning, (4) creates particular relation between lecturer and students that build their motivation to produce a good writing, and (5) gives much knowledge that develops students' intelligence to produce a writing product.

Reflection itself is achieved by the students along with the blogging task. This strategy is supported by Hayland [10] who mentioned several activities to give students experience as reflective writers, such as giving preliminary task, sharing interest between students and lecturer and giving some aspects in which students need to answer to encourage reflection. 


\section{The influences of Using Blog for students in English Writing}

There are several influences toward an activity using a blog for students in English Writing [6. Those are as a guide to creating a section for findings and discussions in this paper.

1) A blog facilitates the students' critical thinking,

2) A blog provides examples for students for modeling and learning,

3) A blog affects the students' quality of writing,

4) A blog facilitates meaningful learning for students,

5) A blog gives students a purpose for writing

This reference is used to guide the researcher to collect the data of observation. Observation gives a chance to the researcher to collect actual report of structural document about participants' activity in which the participants carry out writing task and learn how to write [11]. While observation method for this study is used to know and report students' activity on their personal blog.

\section{Definition of Task-Based Language Teaching}

Richards, Platt, and Weber in Ellis [12] state that task-based language teaching is an activity that is followed by specific goals to investigate student progress in language learning, such as how students understand the purpose of a language based on a task. The Task-based Language Teaching (TBLT) theory is used in this paper to design instruments. The task-based approach has a purpose of providing chances for the teacher to conduct a research based on policy. It becomes a basic way to find many problems related to students' skill both oral and written language in teachinglearning activities which are created based on the purpose of a language [13]. The researcher considers to use TBLT theory because it is appropriate with a basic design of the research procedures which are conducted.

\section{Task-Based Lesson Design in Academic Writing Course}

Task-based language teaching is related to task-based lesson such as a writing practice of English Language subject in school. Ellis, R. [12] states that a task-based lesson is a task deliberately designed to achieve the purposes of that lesson. All of the purposes in teaching practice are always mentioned in the syllabus, and there are typically three principal phases in learning process;

1) Pre-task phase

It is the first step in teaching strategies. This action is focused on any activities to give an explanation, to illustrate an example and to prepare students doing a particular task, such as the lecturer gives a chance to students to think a plan and make a note to finish blogging job based on the schedule.

2) During mission phase

The second step focused on doing the task itself based on an instruction and program, such as the lecturer gives an instruction to create a new personal blog and edit the blog profile. This step pushes the students to do the task under the particular condition and situation.

3) Post-task phase 
It is the last step. In this step, all tasks done, then at the end of the job, the students report the progress to the lecturer. Such as each of students collects a personal blog link that has blog log and gives it to the lecturer.

\section{CURRENT STUDY}

In this paper, the researcher formulates the problem in the form of questions as stated below:

1. How does blogging task give postgraduate students an opportunity to express personal opinions about certain topics and interests in writing blog entries?

2. What are the postgraduate students' perceptions about the use of a personal blog as a platform for reflective learning assisted peer review activity?

\section{METHODOLOGY}

The researcher used case study method involving one class of postgraduate students in one of State Universities in Surakarta, Indonesia. The case study method was used to report students' activities in academic writing class. The specific activity was to observe students' activity when doing a blogging task. The Academic Writing course has 18 meetings in a semester. Based on the syllabus, one meeting in a week takes one and a half hours. An assessment that is related to write blog entries takes $20 \%$ from the whole of assembly.

\section{Participants}

The participants were 30 students. Because of the population target was a just available class, then this research used total sampling. All students were freshmen in a different range of age, gender, origin, and background study. Not all data of students were used for this paper. This paper just served several data of interview.

\section{Data Collection and Analysis}

The researcher gathered the data from observing blog pages and doing an interview. Observing was started by students' report for blog link, then tracking students' activity on their personal blog. The main purpose of observation was to obtain data from all student activities related to the use of blogs in which the researcher observed each student's blog to ensure students to get experiences to post summarized journals, and to comment friends' work. In addition, the researcher used semi-structure interview protocol as guidance to conduct the interview in the field. The purpose of interview was to get students' opinions about the use of blog as reflective learning. After the researcher interviewed the students, the data of interview were transcribed and analyzed to know efficiency and benefit using a blog in academic writing course. Qualitative data from blog posts, peer feedback, and open-ended interview represented the real condition of data in the field. 


\section{Procedure}

In this concept, the researcher focused on a classroom task. The researcher used the instructor's syllabus of academic writing course as a reference, and was also adopted a framework for designing task-based lesson [12]:

Table I. A framework of Academic Writing Task

\begin{tabular}{|c|c|}
\hline Phase & Academic Writing Task \\
\hline A. Pre-task & $\begin{array}{ll}\text { - } & \text { Asked to find several Journals related to personal interest } \\
\text { - } & \text { Assigned reading those journals } \\
\text { - } & \text { Requested to make a personal blog }\end{array}$ \\
\hline $\begin{array}{l}\text { B. During task } \\
\text { (outside of } \\
\text { class) }\end{array}$ & $\begin{array}{l}\text { - Review five journals that are the most interesting, } \\
\text { - } \quad \text { and post 150-200 words utilizing own words (or } \\
\text { paraphrasing) in a personal blog }\end{array}$ \\
\hline C. Post-task & $\begin{array}{ll}\text { - } & \text { Collecting blog links and sharing each other } \\
\text { - } & \text { Giving peer feedback or constructive comments }\end{array}$ \\
\hline
\end{tabular}

In pre-task phase, the instructor gave the explicit instruction to students to search several journals related to personal interest, at least 30-40 journals in the first meeting. The next meeting, she assigned students to read those journals and ask them to make a personal blog site as homework. To pass this task, in the third meeting, the students should report their blog's link (see Figure 1).

In during-task phase, the instructor gave an instruction that students were asked to review the five most interesting journals, and posted 150-200 words utilizing own words (or paraphrasing) in their personal blog. This task was done out of class. Each week students were responsible for posting one or two blog entry based on the articles that they reviewed (see Figure 2 for example).

In post-task phase, the students were asked to collect blog links and share each other. Once all blog links were collected, the students had obligation to give feedback or constructive comments in comment box (under the blog post). In this activities, they were only required to provide feedback on the content of review articles from other participants (see Figure 3).

At the end of the post-task phase, the researcher used semi-structure interview consisted of six main issues as protocol. This interview had a purpose to get data how students' experiences using a blog as media of learning. In a final interview, the researcher prepared three until five students as the samples. The interview section of each person took approximately 30 minutes at most. Interview data were recorded and stored by a digital device, such as smartphone which had recorder application. The original data were analyzed based on the research question. 


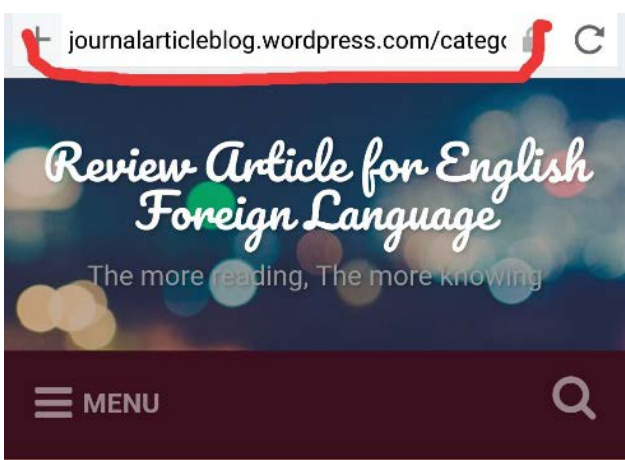

CATEGORY: FIND REVIEW HERE

The Impact of MALL

Figure 1. A Snapshot of Student's Personal Blog

\section{The Impact of MALL}

Title : A STUDY ON THE IMPACT OF MALL (MOBILE ASSISTED LANGUAGE LEARNING) ON EFL LEARNERS' READING COMPREHENSION Source International Journal of English Language Teaching Published by European Centre for Research Training and Development UK (www.eajournals.org) Volume/Date : Vol.4, No.2, pp.58-69, February 2016

Author : Leila Khubyari and Mehry Haddad Narafshan (Ph.D) Review : : In this research,...

Continue Reading $\rightarrow$

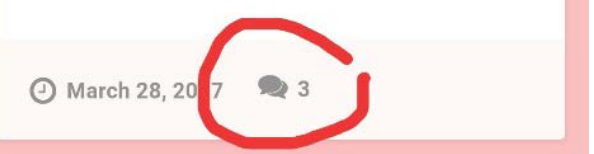

Figure 2: A Blog Page with Article 


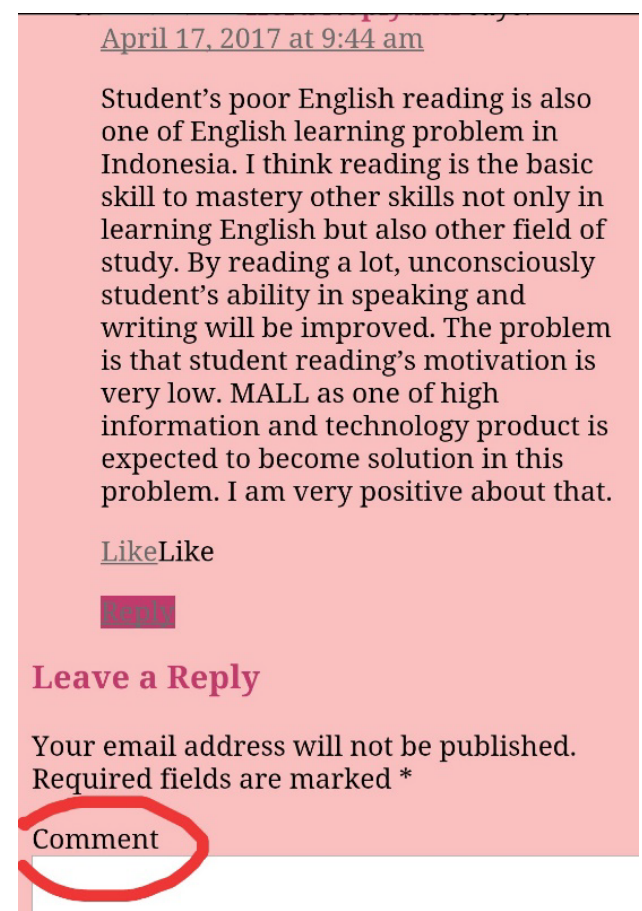

Figure 3: A Blog Page with a Comment

\section{FINDING AND DISCUSSION}

\section{Qualitative data: Students' Blogging Experience}

Table II: Overview of the interviews: Duration and writing/blogging performance

\begin{tabular}{|l|c|c|c|}
\hline \multicolumn{1}{|c|}{ Student/Gender } & $\begin{array}{c}\text { Interview time } \\
\text { (min : sec) }\end{array}$ & Total Blog Entries & $\begin{array}{c}\text { Comments } \\
\text { Received }\end{array}$ \\
\hline MS02/M & $28: 25$ & 5 & 5 \\
\hline MS05/F & $27: 17$ & 5 & 5 \\
\hline MS08/F & $25: 47$ & 5 & 5 \\
\hline MS12/M & $30: 50$ & 5 & 5 \\
\hline
\end{tabular}

From table II, it reports lists each participant's blogging activity and the length of interview duration. All students had done the task well. It can be seen on table II each student wrote 5 blog entries and gave 5 comments to friend's comment box in order to fulfill the blogging task. While, the mean of interview duration itself was 27 minutes of the whole interview. Because this research used case study method, all the data from table II just gave final condition after the students accomplished all instructions. It was in contrast to experimental research which was done by other research, the data revealed the students' score progress before and after the students got a treatment, and all reader could see the differences of students' writing performance from starting the research until the end [14]. 


\section{The scholars' perceptions about the usefulness of peer review}

In this part, the researcher discusses the result of collecting data through a semistructured interview about the usefulness of peer review. Peer review is one of techniques used by the researcher to give students an experience as reflective writer. Two codes are chosen to indicate both the researcher and the participants, such as: CSR stands for a Case Study Researcher and MS01 stands for Master Scholar 01. The number 01 means that the first participant in the list of samples. The followings are three dialogue samples in the interview asking question related to peer comment activity:

a. Interview MS05

CSR : .... Okay, then what do you think that giving peer feedbacks or comments are one of ways to develop critical thinking?

MS05 : I agree that it (blogging) is for developing critical thinking, because based on comments that I read, some focused to give a comment toward content, some focused to give a comment about grammar, some focused to give a comment about research itself (the research that the author chose). So... because the perspectives of students are different, each of students is also different. Their criticism is very helpful for me to improve.

CSR : So, do you think that critical thinking is used when doing peer feedback?

MS05 : Yes, because each of students has different perspective.

CSR : mmm... okay Based on those reasons... so you think you got many inputs from that (activity).

MS05 : yup...

b. Interview MS08

CSR : ...that we discussed before about peer feedbacks... now peer feedbacks from your friends are one of ways to develop critical thinking? Do you agree or not? What is your opinion about that?

MS08 : mmm... I agree, because from comments that they (friends) give, Sometime pop up a question. Based on the question, sometimes triggers a debate-table. Here, in a debate-table issue... sometimes... can help.... Mmm...

CSR : to develop critical thinking? ...

MS08 : yup, it can...

CSR : what are their comments that use critical thinking skill?

MS08 : about peer comments.... Mmm... so far, they just do "asking”. So, I think, this activity is more like referring to me for...mmm... (more active), I mean that I did more explanation about what I already wrote (in blog entries).

CSR :mmm... Okay... 
c. Interview MS12

CSR : ... based on your opinion, giving peer feedbacks... I mean that in the concept of blogging task... are one of ways to develop critical thinking. What do you think about the statement?

MS12 : Yeaa... I agree, because talking about "giving a comment" is the same as criticizing about something. So, if someone does not have critical thinking or criticism, it will be hard. But if there is an obligation to comment or to criticize (particular issue). Yeaa... In the first time, someone might give a critic that just....mmm... giving a comment... no.....mmm... without important point of view. The other event, someone might give constructive critic (because of an obligation)....

CSR : okay, it is enough.... Go on to the next question.

Three dialogues above were taken as samples to answer the question in this paper. The researcher gave the same treatment to all respondents such as they got the same instructions, questions and situations. These three samples represent most of students' perceptions about doing peer comments. The researcher concludes that all respondents agree that giving peer feedbacks or comments are one of ways to develop critical thinking. Several students felt that they got many benefits when they worked on reading and commenting task. The other students felt making peer comment was quite difficult.

Although the instruction just required the students to comment on the content of friends' summarized journal, based on interview result, most students confessed that their friends also concerned to measure writing product related to grammar and vocabulary. It supported the data from observing blog pages in which the students focused to correct their writing when they should upload it on blog. Based on this result, more intensive activity using blogging task can be developed in academic writing course in order to create master students' writing experience in EFL be better. In addition, the personal blog used by students proved that it gave students an opportunity to create and build their own writing skill without the limited creations and rules.

The result above is important for every lecturer to evaluate material and instructional task in English syllabus, for example: a lecturer can join together in the process of giving comment in a student's personal blog, or the student should tell in front of the class what he/she gets from doing peer comment, then it can be evaluated together. This is also an evidence for the other researchers that the concept of critical thinking itself can be used to improve students' English skill. While, the important note should be done before other researchers want to conduct the same topic with the different condition and sample. They need to consider great plans to design a research based on the weakness of this research.

\section{CONCLUSION}

In conclusion, this paper presented the factual data that gave a further contribution to readers' understanding toward the use of a personal blog as a platform in reflective learning and the usefulness of peer review on blogging task. The collecting data from an observation and an interview has related results. The 
blog project succeed in creating online learning as good experience for advanced language students. This research proves that a personal blog can build students' critical thinking, provide examples for students for modeling and learning, affect students' writing quality, facilitate meaningful learning for students, and give students a purpose for writing. However, this research has several weaknesses which should be considered by other researchers, such as this research just used a limited explanation of the observing students' blog pages and blog comment post. The other research can conduct the same research with a certain treatment to get data which can show the improving of students' writing skill from pre-task at the beginning of task and post-task at the end of task.

\section{REFERENCES}

[1] Lee, L. (2010). Fostering Reflective Writing and Interactive Exchange through Blogging in an Advanced Language Course. European Association for Computer Assisted Language Learning, 212-227[1].

[2] Montero F., B., \& Perez S., C. (2010). A research on blogging as a platform to enhance language skills. Procedia Social and Behavioral Sciences, 773-777[1].

[3] Eksi, G. Y. (2013). Peer Review versus Teacher feedback in process writing. How Effective? IJAES, Vol. 13 No.1 Pg Np.34[1].

[4] Al-Qallaf, C. L.-M. (2016). The impact of blogs on teaching English as a foreign language. Digital literacy and digital content supports learning, 522-546 [1].

[5] Kabachinski, J. ( 2007). The Blogosphere. Biomedical Instrumentation \& Technology, 379[1].

[6] Zhang, D. (2009). The Application of Blog in English Writing. Journal of Cambridge Studies, Vol 4. No.1 pp. 64-72[1].

[7] Holland, B. A. (2016). Factors Influencing Faculty Engagement-Then, Now, and Future. Journal of Higher Education Outreach and Engagement, 73[1].

[8] Farrell, T. S. (2014). "Teacher You are Stupid!"- Cultivating a Reflective Disposition. The Electronic Journal for English as Second language, Vol.8 No.3 pp. 1-10[1].

[9] Xie, Y., \& Lin, S.-Y. (2016). Tagclouds and group cognition: Effect of tagging support on students' reflective learning in team blogs. British Journal of Educational Technology, Vol.47 No.6[1].

[10] Hayland, K. (2007). English for Professional Academic Purposes: writing for scholarly publication. Teaching Language Purposefully: English for Specific Purposes in Theory and Practice, 1-27[1].

[11] Hayland, K. (2009). Researching Writing. Research Method in Applied Linguistic, 191-204[3].

[12] Ellis, R. (2003). Task-based language learning and Teaching. Oxford: OUP[3].

[13] Nunan, D. (2004). Task-Based Language Teaching: From theory to classroom practice. Cambridge: Cambridge University Press[3].

[14] Lin, M. H. (2015). Learner-centered Blogging: A Preliminary Investigation of EFL Student Writers' Experience. Educational Technology \& Society, 446-455[1]. 
[15] Bailey, S. (2003). Writing: A Practical Guide for students. the USA and Canada: RoutledgeFalmer [2].

[16] Shehadeh, A., \& Coombe, C. (2010). Applications of Task-Based Learning in TESOL. Teachers of English to Speakers of Other Languages, Inc.(TESOL), 1-7[1]. 